\title{
FUNDAMENTALISM AS A CHALLENGE FOR RELIGIOUS EDUCATION
}

\author{
Heinz Streib \\ University of Bielefeld
}

\begin{abstract}
Empirical research on fundamentalist biographies-presented are three case studies and a summary of research results-demonstrate the complex biographical-motivational factors for fundamentalist turns, but also a transformational potential. Explaining fundamentalist conversion and deconversion within a theoretical framework of fundamentalism as "modern anti-modernism" and as "dislocation of religious styles” opens up a new perspective on the goals of religious education: to transcend the teaching of pure factual knowledge, to open up an atmosphere of "care of souls," to aim at overcoming literal understanding, and to engage in a creative laboratory for thought experiments in order to accompany fundamentalist young people into processes of transformation.
\end{abstract}

Public concern on fundamentalism is in the news almost every day. It is presented as antidemocratic, antimodern, and mostly violent, as global danger caused by militant minorities who want to bomb societies back into premodern times. Such a highly political and global perspective, however, as it is reflected in the Chicago Fundamentalism Project (cf. e.g., Marty and Appleby 1994), should not divert attention from the fact that there are also quiet and apolitical currents within the fundamentalist movements. It should not obscure the fact that there is individual biographical development that may open up opportunities to change one's beliefs, to engage in deconversion and transformation, to find new biographical trajectories - a development that may be typical, especially for the present generation. In its apolitical version, however, fundamentalism presents a challenge-for religious education as well.

Generation X biographies may be of special interest here. In his stimulating analysis, Beaudoin (1998) portrays the specific way of how GenX adopts religious orientations, remains suspicious toward institutions and traditions, and puzzles together its own religiosity whose 
bricolage character can be seen from my own studies as well (Streib 1998a). Beaudoin's portrait of GenX’s "irreverence as a spiritual gift" (Beaudon 1998:179), however, raises the question whether such an appreciation of irreverent tendencies should be extended to fundamentalist orientations as well. When GenX biographies display fundamentalist tendencies and phases, what are the effects on religious development? A closer look is needed; more biographical research is necessary.

Political concern about so-called sects and psychocults led the Federal German Parliament to set up an Enquête Commission. Its report (Deutscher Bundestag 1998), however, reflects an interesting learning process: The Enquête Commission generally arrived at the moderate conclusion that new religious movements, fundamentalism, and psychogroups "do not pose a threat for government and society or for any of the relevant domains in society" (284). As one of the scientists, who helped to alleviate the politicians' concern, I presented results of qualitative-biographical research on members and ex-members of Christian-fundamentalist groups and organizations. The advantage of qualitative-biographical research is that it offers insights into the deep structures of the biographical dynamics in a diachronic (archeological and teleological) perspective that is reflected in the narrative dynamic. Thus, it may contribute to a fresh understanding of fundamentalism. Before summarizing results, discussing the implications for our understanding of fundamentalism and drawing conclusions for religious education, three case studies will be presented.

\section{CASE STUDIES}

\section{Sarah}

Sarah (21 years old at the time of the interview) grew up in a fundamentalist family together with three older and three younger brothers and sisters. Her mother took care of the household, her father worked as a clerk in a firm. Sarah remembers her father as an authoritarian and cruel person. As members of a fundamentalist small church, Sarah's parents raised their children in the thought system and rules of this church. After leaving high school, Sarah left home and began training as a nurse, but she had to abandon that because of psychological problems, and moved back home. Not long after her return, the entire family left this church: her father because he con- 
sidered it not truly Christian enough; Sarah deconverted from the fundamentalist milieu altogether, was driven from home by her parents, moved to a girlfriend's house, and later in with her boyfriend. She began vocational training as an ergotherapist and expected to take the exam soon after the time of the interview.

The dynamic of Sarah's narration manifests her present problems to make something of her life, her anxiety with regard to the challenges she faces, and her hatred of her own biographical past. Her elementary need to feel at home in a warm, caring, and unconditionally-loving environment was not fulfilled by her family. On the contrary, she tells about having been beaten and driven from home. Religion, for Sarah, tastes of a patriarchal-authoritarian and fundamentalist orientation. Sarah considers herself to have been oppressed and exploited. She continues to have difficulties with developing initiative and an ability to cope with conflicts.

In contrast to these negative experiences and developments, Sarah also reports positive experiences within the fundamentalist milieu: feelings of community in the church that compensated for the devastating atmosphere in the family. For years, Sarah lived in the milieu and thought system of that fundamentalist group and was convinced to be on the right track.

It was due to conversations in school and to the model of her older brother, who rebelled against this religious orientation and was also expelled from home, that Sarah gradually came to question the narrow-mindedness of the family's church. An important factor in her final decision to leave the church and home certainly was Sarah's simultaneous (delayed, but all the more vehement) adolescent process of detachment, especially from her father who was both one of the leading figures in their church and her authoritarian father. Her rebellion against her father based on his own contradictions between word and deed thus went parallel to her rebellion against his faith.

While Sarah, during late childhood and adolescence, did not possess the resilience and strength to challenge her father's worldview and dissociate herself from it, she mustered the courage to find her own way and to criticize the inconsistencies in her church's worldview and the lack of warmth in the relations between church members only a few years before the interview. As a result of her ever more acute criticism and her increasing independence, Sarah was shunned and emotionally rejected by church members and her family alike. This suffering, which resulted in suicidal tendencies, induced her to risk 
limited confrontation with her environment and, more importantly, to escape from it.

In retrospect Sarah refers to some rare, but highly significant situations that helped her develop a mode of thinking, which differed from that of her fundamentalist milieu and helped her to finally find a way out-elucidating moments with her mother, opportunities to talk about questions that Sarah had heard in religious education class.

\section{Heike}

Heike (22 years old at the time of the interview) grew up with father, mother, and, for the first three years of her life, stepbrother. Besides some nice Sunday excursions and holidays, Heike remembers quarrels, brawls, and shouting between her parents. Her father frequently had outbursts of rage and her mother, whom she portrays as having been closer to her, often neglected her and beat her for punishment. Heike was frequently left alone behind locked doors when her parents went out for the evening.

Heike had been baptized in the Methodist (minority) church, but religion obviously did not play a role in the family. While Heike, like many of her generation, participated in the confirmation class of the Protestant (mainstream) church, she later converted to Catholicism. Heike was not able to share anything about her religious feelings with neither her father nor her mother-Heike's parents were divorced only a few years before the interview. When she was about 20 , the relationship with her mother was broken off.

Since early childhood, Heike remembers having seen frightening things and beings at night in her room that her mother could not see when she came to find out why Heike was screaming. Heike talks about "some sort of ugly creatures, which were standing at the side of my bed."

I was at home, all on my own, my mother was with the upstairs neighbour, and then they came and I saw a spider in my corner. Not real, not really real, and I climbed onto the wardrobe, imagine a toddler climbing the wardrobe ... and I stayed up there and shouted at the top of my lungs: "Mama, they're there again, they're there again." She didn't understand and I said: "Back in that corner, they're back there.” I kept seeing things, my mother thought I was crazy, but the doctor said I was mentally fit and completely healthy.

Later in the interview, Heike speaks about another experience of that sort: 
They were horribly ugly, I don't know how to describe them, the colour, they were a sort of green, between green and burnt. And they had fire, well they were fairly evil. They kept following me, they wanted to kill me or something. I only know one thing, I was there, I slept there, I woke up and I called for my mother, but she didn't hear me, although I shouted. And then I was afraid, then I went to the door, and I was pulled back from the door by my bed. By something or other. But, I didn't see, what pulled me. Then I screamed and I nearly died. Well, then there was my mother, she had heard the noise and came in, and she asked what was the matter with me, I was as white as a sheet, I was just barely alive, my heart was hardly beating. I said: “Mama, I think I'm dying, I’m dying, they've come to get me, they've come to get me!" That may sound a bit fantastic, like in a film or something.

Later, during early adolescence, Heike started drawing her frightening beings and learned to explain where they came from: Hell. But only at the age of about sixteen did Heike begin to engage in occult practices. In a small group, which included her mother, they called upon the demons, and Heike had the experience of being the medium. The seances, especially the third, increased Heike's anxiety: She called the beings that she had seen coming for her in her bad daydreams. After having read books, especially volumes on archeological art from Babylon, Heike was able to identify one of the beings as the demon Passusu. This information, together with the occult sessions, resulted in a deep depression. Heike tells about three attempted suicides.

During this episode of depression Heike sought help in traditional religion. But she did not find what she was looking for in the Protestant church, where she attended confirmation class. She found it in the Catholic Church: Once, during mass, she saw the priest who was to become the most important person for her. Heike was deeply irritated by his gaze, she knew that he would be the one to perform an exorcism. The Catholic priest was a fundamentalist, and this is how Heike found her way into a fundamentalist faith and thought system in which the existence of her demonic world was not questioned. On the contrary, the demons were taken quite seriously and exorcised during Heike's (re-) baptism.

This was the most beautiful day, the most important event in Heike's life, and her account, she says, can hardly cover what she experienced. She saw the light. She felt really at home for the first time in her life. She could talk to God whose presence she felt overwhelmingly. About how she felt after the baptism ceremony and communion, Heike says: 
I didn't want to leave. When they called me away to celebrate . . ., I wanted to stay, I said, give me some more, give me a bit more! Well, that was a completely new experience, and suddenly the happiness, the warmth and what you suddenly feel within yourself, it was as if someone had put a coat around me for protection and said ... that's what it was like. That God held me in his arms. That's what it was like.

At the time of the interview, Heike was still strongly involved and immersed in this fundamentalist milieu. Her room, where the interview took place, was packed with statues of the Holy Virgin.

\section{Thomas}

Thomas (48 years old at the time of the interview) lived during his childhood and adolescence in a big city in northern Germany. After graduating from high school he went to university to study biology to become a science teacher. Having passed his first teacher examination and completed his teacher training, he did not get full-time employment as teacher for reasons we do not know, and for the following 20 years earned his living by doing different jobs here and there. At the time of the interview, Thomas lived with a woman, her two young children, and an eight-month-old infant who was their common child.

As to the reason for his attraction to sects and fundamentalist groups, Thomas gave us the story that, as a student at the university, he found it both strange and appealing to have a sign hung on the door of his next door neighbor's flat: "Don't Disturb-Meditation." Thomas explains his attraction with his feeling at that time:

\footnotetext{
. . . I had the feeling, about myself that this is not all, how I live. Well, it was the search for more intensity ... for a certain kind of release from burdens, which I felt, with which, which perhaps were not always clear ... what it was. But a little lack of freedom, together with guilt, being dependent on ... my family, uh, perhaps also a lack of self-confidence, I would say, was a kind of basic structure ...
}

Years later, as Thomas was approaching his second exams in practical teacher training and felt the stress and pressure of these forthcoming exams, he was introduced to Bhagwan meditation by a friend. After a first-time visit he remained in the Bhagwan movement for three or four years, living in various communes. As reasons for leaving, Thomas mentions that the ideology of the movement became too narrow for him and that he felt too oppressed and was not satisfied with open sexuality. After these years-his girlfriend had gone to In- 
dia-Thomas moved back to his hometown. There, through an old friend, he found his way into a bioenergetics group (which only went by this name obviously, but was a hardcore encounter group). Thomas tells us about a seven-day workshop, where everybody was confined to a room without eating or sleeping and about having similar exercises every week. Surprisingly, however, his account is not completely negative:

... standing without moving which after some time hurts so much that you begin to scream and to tremble ... uh, and then there come such basic feelings, there comes the screaming of a three-year-old ... uh, or a rage or this and that, then this system of this person was uh actually a therapeutic village uh, let's say always, always living in therapy ... uh, to liberate yourself. ...

Thomas also tells us that he has had good experiences in this group. After the group leader's death, Thomas left and went on to live a rather quiet life, belonging to the church choir of a mainstream Protestant parish, and earning his living as a taxi driver and as a market salesman once a week. Then he met Scientology agents on the street and agreed to take a "personality test"-and, unlike one of his friends, who left Scientology after a first visit, Thomas became involved.

... yes I took these tests and somehow I had been caught, though I really did not want to go there (fast) I wouldn't have gone there at all first . . . but once I was there I said, well, what of it, then also I got somewhat curious and certainly this ... this desire again for that ... uh redemption, liberation from the past, from a very burdensome past ... yes, that was it and they promised me something...they had also some sort of therapy: ... they certainly now uh they are certainly harder, let's say more intransignant, more sectarian than anything I have ever seen before. ...

Thomas describes his attitude towards this new group-in contrast to his attitude toward the previous groups - in terms of cost and profit. Although Thomas talks extensively about a positive experience in Scientology therapy, the healing of a falling trauma that had plagued him very often in his dreams, his portrait of Scientology is generally negative and critical. He felt particularly uncomfortable with the lie detector. Thomas, however, was not able to leave the organization of his own volition. This was possible for him only in the context of joining a new group.

This began again by accident: Thomas read an advertisement "Tonight: Gospel Meeting" and followed this invitation. He went to this 
meeting in a charismatic church, his feeling of strangeness dissipating fast and being replaced by deep fascination. Thomas was especially impressed by a nice young woman's account who told him about Jesus who was alive and had helped her; and Thomas was not sure whether he was infatuated with the woman or attracted by her faith. In any case, he decided to come back for Sunday service. Thomas remembers at his first visit to this gospel church that he had to go to the bathroom to cry, he was so emotionally overwhelmed when the group started to dance and praise the Lord. This experience affected Thomas so deeply that he stayed and became a member of this fundamentalist charismatic church. This is where he met a woman who urged him to terminate his relationship with Scientology; and Thomas responded immediately, stopping a check, and never returning to Scientology.

It appears surprising that Thomas, after his extensive tour through groups that are rather critical of Christianity, obviously had no problem with fundamentalist thinking in this group. This points to a characteristic attitude that we can observe throughout Thomas's tour: For him, ideology or doctrinal truth did not play a decisive role in joining a group and did not seem to have made any difference - except when he was required to submit, then he had to get away. Rather, motivation and fascination for Thomas consisted in the feelings of relief and in the therapeutic effect the group provided for him.

At the time of the interview, Thomas was living a rather secluded life together with his new partner and their children. Faithfulness to this woman is important to him, and he tells us that he reads to the children from the children's Bible. Looking back upon his tour through the various groups and organizations, Thomas uses biblical language, a quote from Paul to explain in what sense he regards himself as a Christian, maintaining that he does not want to be a prisoner of Christ.

. . . and I did not want to be a prisoner of Christ so to speak . . that uh, I have decided against that, I have realized . . . insofar I am . . . uh, if this is a Christian and when I understand this now as a Christian, then I am not a Christian any more.... I am not a disciple of Jesus... in that sense . . . uh . . . but I would not say Christianity is the worst there is, but I would say that I have said there I have experienced liberation, but I have said also ... uh can say also, in this se- where I really say a sect, Scientology ... there this has helped me and . . . with Bhagwan that . . has helped me, because in each . . . a good friend she says I have taken a little bit from everywhere, from Anthroposophers this, from Bhagwan that. . . 
We have no reason to doubt Thomas's self-reflective summary: in each group he found, at least temporarily, some relief. For Thomas, conversion is not a once-in-a-lifetime experience, but rather a repeated one of getting deeply involved. He was repeatedly able to find a temporary solution, and his rebellion against demands for submission repeatedly motivated him to leave these groups. Thomas's self-reflective account suggests to call him, in my terms, an "accumulative heretic" and qualifies him as a typical case of Generation $\mathrm{X}$ religion that appears here as continuous ambivalence between deep involvement and repeated irreverence.

Is Thomas both a compulsory convert and a compulsory heretic without any change? Upon following his narrative carefully, a transformation process becomes visible which has developed through the long tour across all the different groups and movements, at the end of which a more self-assertive, more individual person emerged. His almost restless search has come to an end not only in warmth and embeddedness, but also in responsibility with a nuclear family situation.

\section{RESULTS FROM OUR RESEARCH AND PROPOSALS}

After having presented some of the cases, I shall now summarize the results of our fundamentalism project. ${ }^{1}$ First, we did not find one typical biographical structure of fundamentalist converts or deconverts. On the contrary, we conclude that there is no typical sect biography and no typical set of motivational factors. We certainly searched for "life themes" or "themata" 2 which the subjects bring with them into fundamentalist milieus. While we were able to identify childhood trauma, childhood anxiety, or unsatisfied hunger for love and accep-

${ }^{1}$ Our research project on Christian-fundamentalist converts and defectors has been part of a larger study proposed to the Enquête Commission of the Deutsche Bundestag on so-called sects and psychogroups; it was funded by the German Parliament. Out of a total of twenty-two narrative interviews with people who left the fundamentalist milieu or organization ("deconverts" or "ex-members") and with people who remain in them ("insiders" or "converts"), twelve were selected for interpretation. Our analytical interest was focused on the relation between "religious career" and biography; on the question of personality change and continuity; and on questions of identity in the situation of dramatic processes of conversion and transformation. (For more details on results and method see Streib 1998a; 1999a.)

${ }^{2}$ My concept of life themes or themata refers to Noam's (1990). (See also Noam 1985; Noam et al. 1991.) 
tance, we only found motivational factors of the same kind found in nonfundamentalist biographies as well.

Second, contrastive comparison of the cases permits locating them within a typology. We were able to identify three types of fundamentalist careers: 1) a tradition determined type, 2) the monoconvert, who converts as it were a once-in-a-lifetime to a religious orientation which he or she did not have before, and 3 ) the accumulative heretic ${ }^{3}$ whose biography is a tour through different religious orientations. The latter I regard as a novel type of religious socialization. Sarah is a typical case for the tradition-guided type of fundamentalist, Heike belongs to the monoconverts, and Thomas is a very typical case of an accumulative heretic. Accumulative heretics nevertheless convert to fundamentalist belief systems - albeit only temporarily. This typification suggests a clarification of the nature of fundamentalism and fundamentalist conversion.

Third, a special focus in our analysis of the interview material was on the biographical dynamic and development. Do fundamentalist milieus have problem-reinforcing or problem-reducing effects? Is there transformation or decompensation? Despite all the struggling with traumatic life themata, problem-reducing effects and transformation will indeed result. Thomas, for example, has undergone a transformation during his journey through a variety of religious milieus, which finally enabled him to cope with his unrelieved desire for unconditional love. I consider the documentation of these transformation processes the most important result of our research. Comparison of the cases reveals that transformation and decompensation are not distributed equally among them. The tendency could be demonstrated that the tradition determined type suffers more negative consequences and in some cases decompensation, while the accumulative heretic develops more into transformation.

It follows clearly from these results of our study that we do not need stronger anti-cultist legislation, but more help for the individual. Helping the individual, however, means professional counseling and therapeutic service. The final report of the Enquête Commission reflects to some degree the results of our empirical studies. One of its main suggestions consistently was to provide funds for counseling and educating the public about new religious movements and psycho-cults.

${ }^{3}$ The concept of "heretic," which is not meant as a derogative for deviating religious orientations, but only to indicate the imperative to choose, is developed by Berger (1979) in his book The Heretical Imperative. 
Such help has both a prophylactic and a therapeutic dimension. Therapy should be provided to help the troubled individual to work on and cope with traumatic life themes that he or she took into the fundamentalist or new religious milieu and that did not find resolution there. It is necessary to assist these transformation processes. The prophylactic aspect focuses on school education and public education. Religious educators are called upon to make explicit their own contribution to the prophylactic response to the fundamentalist challenge. But what should people learn? What are the specific goals of religious education when it tackles the fundamentalist challenge? This is what I would like to make explicit in the final part of this article. First, I shall highlight some features of the concept of fundamentalism from which I draw my educational conclusions.

\section{FUNDAMENTALISM-CONCEPTS AND EXPLANATIONS}

I will briefly refer to an interpretation of fundamentalism in terms of sociology and developmental psychology.

\section{Fundamentalism as Modern Antimodernism}

To understand fundamentalism as modern antimodernism follows from sociological analysis, as Küenzlen $(1994,1996)$ suggests. When we trace fundamentalism's basic orientations back to its origin, to the point where the first people and publications proudly identified themselves as fundamentalists, it appears as reaction against developments in science, in theology, in society, and in the churches. For an adequate description of fundamentalism, we can draw on the claims of the fundamentalist manifesto:

1. infallibility and literal understanding of the Scripture;

2. literal understanding of some basic propositions such as virgin birth, bodily resurrection, and the return of Jesus;

3. rejection of the results of modern science wherever they contradict this literal understanding; and

4. the claim that only people subscribing to this manifesto are truly religious.

From this self-description, it is obvious that fundamentalism is a reaction to modernity. However, this reaction to modernization processes 
itself is using rather advanced "modern" scientific argumentation, means of communication, and organizational strategies: It is modern antimodernism.

\section{Fundamentalism as Dislocation of Religious Styles}

How does the thesis "fundamentalism is modern antimodernism" translate into terms of developmental psychology? At first sight, such a translation appears impossible, since the structural-developmental theories at hand appear to be in line with the progressive-teleological myth of modernity and, therefore, seem not to be capable of regression. The religious styles perspective,${ }^{4}$ however, while certainly originating in the family of theories which consider the Piagetian developmental model for various other domains, tries to take a broader perspective and to qualify the cognitive and structural one-sidedness in the Piagetian family of theories. The most significant qualifications of structural-developmental theory that the religious styles perspective suggests result from a decided focus on inter-personality, ${ }^{5}$ from a deeper account for the psychodynamic dimension, and from special attention to the religious milieu. Finally, the milestone model is the most adequate to describe religious development, since it suggests not stages, but rather styles. ${ }^{6}$ Development, then, appears as a cumulative sequence of styles that supposedly peak at a certain point in life. These styles, however, are not assumed to disappear, but rather to decline and form a layer in one's psychic resources that can be recalled and revitalized later when the need arises.

The religious styles perspective can be described briefly as follows: After the subjective religious style, which is predominant in early childhood when the symbiotic relation to the care takers still prevails and the development of basic trust is crucial, the reciprocal-instrumental or do-ut-des religious style develops when the child becomes aware of his or her own needs and interests as opposed to those of other people. Do-ut-des is the basic pattern for both the interpersonal

${ }^{4}$ Taking up the thread of my doctoral dissertation (Streib 1991), I have recently proposed a modification of structural-developmental theory of religion (Streib 1997) of Oser's theory of religious development (Oser and Gmünder 1984), and especially of Fowler's (1981) faith development theory, from which a plausible explanation of fundamentalism can be advanced (Streib 2001).

${ }^{5}$ For a revision of structural-developmental theory by focusing on the interpersonal, I refer again to Noam (1985; 1990; Noam et al. 1991). model.

${ }^{6}$ This model of development is inspired by Jane Loevinger's (1976) milestone 
and the God-human relation: Good is what God and the authority persons wish and demand, bad and immoral is what results in punishment-a do-ut-des economy. Means of trade are obedience and observation of religious commandments. The characterization of this style's understanding pattern as "mythic-literal" (Fowler 1981) means that an awareness of the metaphoric or symbolic meaning has not developed yet, that we must not modify any detail of the story or of the religious rules. Literally everything happened precisely as told in the story, literally everything has to be observed exactly as the religious rules prescribe.

During puberty and adolescence, the do-ut-des style normally recedes to the background and is superseded by a new orientation which we call mutual religious style, when the widening of the interpersonal horizon, that is, in the adolescent peer group, and the mutuality of relations permit such development. The new style rests on mutuality in one's religious group and prefers an image of God as a personal partner. The unquestioned security in one's religious group or its contrary: The dependence on their judgment reveals that it is difficult to transcend the ideological and institutional group limits. The capacity to establish one's own critical and reflective point of view has not yet been developed. This is possible in the individuative-systemic religious style, in which the social world is understood as a system in which I have to look for, take and defend my own place. It is the style of identity formation where identity means that through reflection we find our place in society. And this is also true for religious matters: God, society, church, the human being-all have their welldefined places and roles. Finally, we hope for the development of the dialogical religious style, which is able to realize that contradictions and differences need not result in exclusion and hostility toward others, but are opportunities to open up for, and learn from, other people with religious orientations different from our own.

It is obvious that the description of the reciprocal-instrumental or do-ut-des style characterizes exactly what the fundamentalist worldview maintains. ${ }^{7}$ We do not call children fundamentalists, however, but regard this style as one adequate for childhood. We regard as characteristic for fundamentalism only the persistence or revival of the do-ut-des

${ }^{7}$ Fowler (1987), too, has paralleled mythic-literal faith and fundamentalist communities: Mythic-literal faith can, in fundamentalist groups, "constitute the modal level for the community." He suggests to distinguish two kinds of settings: “[It] makes a considerable difference whether this stage is experienced in a community as a way station on a longer journey or as having the characteristic of a final destination" (85). 
style in adolescence and adulthood when most people have already developed mutual or systemic orientations. The systemic style stands for modernity's competencies and requirements, it parallels the sociological notion of modernity. When in the midst of systemic or mutual style development (which is applied to most issues except for religion and existential issues ${ }^{8}$ ) the do-ut-des style reemerges and gains influence, we can speak of a revival or dislocation of styles. This is what happens in fundamentalists. Dislocation is a metaphor from geology and says that the present style is not structurally whole and comprehensive, but has splits and gaps in which something not up-to-date reemerges. The fundamentalist orientation develops the stronger the more the do-ut-des style gains ground and dominates. In this way, the interpretation of fundamentalism as modern antimodernism translates well into the terms of developmental psychology.

\section{THE CHALLENGE TO RELIGIOUS EDUCATION}

\section{Perception and Experience}

Imagine Sarah, Thomas, and Heike sitting in your religious education class. What would you expect them to learn? How would you react? Before the teacher is able to do anything, however, he or she must become aware of the fact that a student may have a fundamentalist orientation. Heike is indeed an interviewee recommended to me by a friend of mine who is a pastor and had Heike in his religious education class. Although he had some debates with her in the classroom, and although he had the strange feeling that Heike must have certain kind of problems, counseling or even personal conversation did not take place- - until Heike came into his office to declare that she wanted to leave the church. I do not tell this story to blame my friend for a sin of omission, but to draw attention to a serious problem in religious education. Religious education, despite all subject orientation, should be a place for talking personally, speaking about and reflecting one's own religious orientation-practical phenomenology. ${ }^{9}$

\footnotetext{
${ }^{8}$ Hunsberger, Pratt, and Pancer (1994) in their empirical study report the surprising result that complexity of thought, did not mark a difference between fundamentalists and other subjects, except for "existential issues." (Compare also Hunsberger et al. 1996.)

${ }^{9}$ Also in a more general perspective on the concept of religious education, I find striking parallels between the approach I am advocating here and a "new style" phenomenology or the "interpretative approach" developed by Robert Jackson (1998).
} 


\section{Counseling and Pastoral Care in Religious Education}

Religion involves the person very deeply, its content concerns us ultimately (Tillich 1951). The interview material has great value in demonstrating the deep personal involvement in themes and questions that only the ignorant would treat as mere content. Especially for the sake of fundamentalist students, we need to pay new and careful attention to the student's needs. Therefore, I suggest to (re-)consider approaches of counseling and pastoral care for religious education. In an atmosphere of mutual perception and encounter, students will be able to disclose their own religious orientation, and fundamentalists will not need to hide their opinion, "care of souls"to use this old fashioned word — can take place, and deconversion has an opportunity to develop in this environment.

\section{Transformation and the Goal of Religious Autonomy}

Fundamentalists, as our case material demonstrates, are able to engage in transformation. This might encourage religious educators to bear in mind that this potential exists. But can religious education continue to hold on to goals of reflection on religious matters only? Should individuative reflectiveness (Fowler 1981) or religious autonomy (Oser 1988) be still our main educational goals? The answer is yes, but only if there is a decisive qualification of structural-developmental goals.

The explication of the concept of fundamentalism that I have developed above has implications for religious education. When we understand fundamentalist orientations as revival or "dislocation of religious styles," we look back from the actual state of development and inquire how previous orientations can be integrated. We deal with the difference, the clash, and the split-and we ask how dislocation can be overcome to the effect that the present mutual or systemic styles cover more ground. Here, the developmental expectation of religious autonomy is adequate-with one important qualification: Religious autonomy must not be identified with the strict and narrow systemic style of a rational worldview, but stand opposed to the fundamentalists' humorless one-dimensionality. Religious autonomy involves a playful ease which is aware of the fact that knowledge is preliminary and that we think in models. Finally, integration or "healing the dislocation" means to develop the ability to tell and retell, to read and rewrite the story of one's life in one's latest style available. 
Besides, regression, when it is in the service of the ego (cf. Blos 1967; Henseler 1994), can become a helpful perspective in religious education: when the individual revisits patterns of thought and feeling in his life in order to work on them and hopefully to integrate them into his or her present thinking. Viewed from this perspective, what such students need is not developmental impatience and provocative confrontation with the goal of religious autonomy, but rather time. Kegan $(1982,276)$ powerfully advocates such intervention which he calls "joining the person." It is one of the tasks for religious educators indeed to join the fundamentalist meaning-maker, since he or she faces a world that is stimulating up to the point of being meaningthreatening. This means to allow the student to hold his or her own views and to be integrated, even if it is strange to the teacher and the other students. Then it means to cautiously invite some reflection.

Explicating these reflections in educational goals leads me to conclude with a wider perspective, because I suppose that fundamentalism can be taken as a challenge reminding religious education to become again what it should be in the first place. I state this in seven theses:

\section{Some Goals of Religious Education (Not Only) in Response to Fundamentalism}

1. Religious education should be a process dealing with perplexity and astonishment, rather than providing a flood of answers to which the students do not know the question.

2. Religious education should be a "creative laboratory for thought experiments" (cf. Ricoeur 1992; Streib 1998b) and for fiction (cf. Streib 1998b), rather than a curriculum of clear-cut lesson about the facts of one's own religion or another.

3. Religious education has the task of overcoming literal faith (cf. also Tillich 1957, 244), and nurturing the conflict of interpretations, leading to understanding theological truth as outline, model and thought experiment for our time. Therefore, acquaintance with the diversity of theological thinking is an important goal for religious education in response to fundamentalist tendencies.

4. Religious education needs to promote playful ease, rather than humorless narrow-minded factual knowledge. Playful ease is a habit that we expect to be available in an unrestricted and unspoiled way in childhood. Religious educators, however, may need to de- 
velop or regain it for themselves and for their students as a prophylactic competence against fundamentalism. Aren't we invited to "become like the children"?

5. Religious education should nurture the ability to tell and retell, to read and rewrite the story of one's life in one's latest style available.

6. Religious education should put in motion the "Protestant principle" 10 and transcend the concreteness of one's own church, community, and religious tradition-which even exceeds the sphere of religion-in order to reflect on nature, culture, and history "under the aspect of ultimate concern." In short, and to quote Tillich once more, religious education has the goal of opening the students' minds - as deeply as in their unconscious dimension—or the "ultimate mystery of being" (Tillich 1931, 234).

7. Religious education, thus understood, is an aesthetic adventure, rather than an instruction as it were in hermeneutic objectivity (cf. also Zillessen 1994; 1995).

Heinz Streib is professor for Protestant theology (religious education and ecumenical theology) at the University of Bielefeld, Germany.

\section{REFERENCES}

Berger, P. L. 1979. The heretical imperative. Contemporary possibilities of religious affirmation. New York: Doubleday.

Beaudoin, T. 1998. Virtual faith. The Irreverent spiritual quest of generation $x$. San Francisco: Jossey-Bass.

Blos, P. 1967. The second individuation process of adolescence. The Psychoanalytic Study of the Child 22:162-86.

Deutscher Bundestag. 1998. Final report of the Enquête Commission on 'so-called sects and psychogroups'. New religious and ideological communities and psychogroups in the Federal Republik of Germany. Bonn: Deutscher Bundestag.

Fowler, J. W. 1981. Stages of faith. San Francisco: Harper \& Row. 1987. Faith Development and Pastoral Care. Philadelphia: Fortress Press.

Henseler, H. 1994. Religiöses Erleben-Eine Regression im Dienste des Ich? Überlegungen zur Psychogenese der Religiosität. Religion als Chance oder Risiko. Bern: Hans Huber, $169-78$.

Hunsberger, B., Alisat, S., Pancer, S. M., and Pratt, M. 1996. Religious fundamentalism and religious doubts: Content, connections, and complexity of thinking. International Journal for the Psychology of Religion 6:201-20.

Hunsberger, B., Pratt, M., and Pancer S. M. 1994. Religious fundamentalism and integrative complexity of thought. A relationship for existential content only? Journal for the Scientific Study of Religion 33:335-46.

${ }^{10}$ What Tillich (1932; cf. 1929) maintained as one of the essentials of Protestantism and what he called the "Protestant principle" is the self-critical protest against all kinds of denominational congealment and induration (and in here the Protestant churches should be the most self-critical) is most relevant as basic structure for religious education. 
Jackson, R. 1998. Problems and possibilities for phenomenological approaches to religious education. Pp. 47-74 in Religionspädagogik und Phänomenologie. Von der empirischen Wendung zur Lebenswelt, edited by H.-G. Heimbrock. Weinheim: Dt. Studienverlag.

Kegan, R. 1982. The evolving self. Problem and process in human development. Cambridge: Harvard University Press.

Küenzlen, G. 1994. Fundamentalismus: Moderner Antimodernismus. Kultursoziologische Überlegungen. Praktische Theologie 29:43-56.

1996. Religiöser Fundamentalismus - Aufstand gegen die Moderne. Pp. 50-71 in Krise der Immanenz. Religion an den Grenzen der Moderne, edited by H.-J. Höhn. Frankfurt: Fischer.

Loevinger, J. 1976. Ego development: Conceptions and theories. San Francisco: Jossey-Bass.

Noam, G. G. 1985. Stage, phase, and style: The developmental dynamics of the self. Pp. 32146 in Moral education: Theory and application edited by M. Berkowitz and F. Oser. Hillsdale, N.J.: Lawrence Erlbaum.

—_ 1990. Beyond Freud and Piaget: Biographical worlds—Interpersonal self. Pp/ 360-99 in The moral domain, edited by G. Noam and T. Wren. Cambridge: MIT Press.

Noam, G. G., Powers, S. I., Kilkenny, R., and Beedy J. 1991. The interpersonal self in life-span developmental perspective: Theory, measurement, and longitudinal analyses. Pp. 59104 in Life-span development and behavior, vol. 10, edited by P. B. Baltes, D. L. Featherman, and R. M. Lerner. Hillsdale, N.J.: Lawrence Erlbaum.

Marty, M. E., and Appleby, R. S. (eds.). 1994. Accounting for fundamentalisms. The dynamic character of movements. Chicago, London: University of Chicago Press.

Oser, F. K. 1988. Wieviel Religion braucht der Mensch? Erziehung und Entwicklung zur religiösen Autonomie. Gütersloh: Güterloher Verlag.

Oser, F. and Gmünder, P. 1984. Der Mensch-Stufen seiner religiösen Entwicklung. Ein strukturgenetischer Ansatz. Zürich/Köln: Benzinger.

Ricoeur, P. 1992. Oneself as another. Chicago: University of Chicago Press.

Streib, H. 1991. Hermeneutics of Metaphor, Symbol and Narrative in Faith Development Theory. Frankfurt/M.: Peter Lang.

- 1997. Religion als Stilfrage. Zur Revision struktureller Differenzierung von Religion im Blick auf die Analyse der Pluralistisch-religiö sen Lage der Gegenwart. Pp. 48-69 in Archiv für Religionspsychologie 22, edited by N.G. Holm, E. Möde, and H. Petri. Göttingen: Vandenheock \& Rupprecht.

-. 1998a. Aussteiger, Konvertierte und Überzeugte. Kontrastive Analysen zu Einmündung, Karriere, Verbleib und Ausstieg in bzw. aus Neureligiösen und weltanschaulichen Milieus oder Gruppen sowie radikalen christlichen gruppen der ersten Generation. Milieus und Organisationen christlich-fundamentalistischer prägung. Pp. 108-57 in Neue religiöse und ideologische Gemeinschaften und Psychogruppen, Edited by Deutscher Bundestag, Enquête-Kommission, Sogenannte Sekten und Psychogruppen. Hamm: Hoheneck.

- 1998b. The religious educator as story-teller. Suggestions from Paul Ricoeur's work. Religious Education 93: 314-31.

- 1999a. Off-road religion? a narrative approach to fundamentalist and occult orientations of adolescents. Journal of Adolescence 22:255-67.

2001. Faith development theory revisited: The religious styles perspective. International Journal for the Psychology of Religion.

Tillich, P. 1929. Der Protestanismus als krtisches und gestaltendes Prinzip. Pp. 127-49 in:

Main Works/Hauptwerke, Vol. 6. Berlin/New York: deGruyter/Evang. Verlagswerk 1992. . 1931. Zum Problem des evangelischen Religionsunterrichts. Gesammelte Werke.IX. Stuttgart: Evang. Verlagswerk 1967, 233-35.

-. 1951. Systematische Theologie, Bd.1. Stuttgart: Evang Verlagswerk 1958.

- 1957. Theologie der Erziehung. Gesammelte Werke IX. Stuttgart: Evang. Verlagswerk 1967, 236-45.

Zilleßen, D. 1994. Dialog mit dem Fremden. Vorüberlegungen zum interreligiösen Lernen. Eangelischer Erzieher 46:338-47.

- 1995. Lachen und Weinen. Warum wir Gott nicht so eng sehen. Evangelischer Erzieher 47:365-70.

Article submitted: November 1998.

Article accepted: June 1999. 